their energy on modest developments in the technology of launching satellites-making Europa 2 a usable rocket, for example-then it would be possible (and sensible) to force a shotgun marriage between ELDO and the European Space Research Organisation (ESRO). At the same time, it should be possible to use these organizations as means of channelling funds to projects for the development of experimental equipment that could yield important scientific benefits and at the same time help to create a sense of confidence in this new technology within Europe. Here again, it is hard to think that launching facilities would be withheld. Most probably, the United States would be as willing (for a fee) to help as it has been in the past. And if it should come to the worst, there are always the Russians who might be asked to help.

\section{Research Organizalion}

While the House of Commons Select Committee on Science and Technology has been banging again at its favourite drum (see page 64) - the establishment of a Minister for Science and Technology within the structure of the British government-the OECD has produced the first of three reports (The Research System, Vol. 1, obtainable from HMSO, £2.45), a sensitive comparison of the ways in which science research is organized in France, Germany and the United Kingdom. The study owes its existence to OECD's brooding about what was called in the mid-1960s the "technology gap". Its chief interest is its patient description of how varied are the ways in which three closely comparable nations set out to meet similar objectives, and its demonstration of the great diversity of the institutions which have come into being in the process. The fact that the study has been carried out at a time when the resources available for scientific research have ceased to grow and have even begun to decline (by the yardstick of the Gross National Product) makes it especially valuable as a means of anticipating how the current strains within the system should be relieved.

For most governments, but especially for the three covered by the OECD study, the chief objective of current policy is to win more economic or social benefits from the sums being spent on research and development, estimated at 2.0 per cent of the GNP in Germany, 2.2 per cent of the GNP in France and 2.4 per cent of the GNP in the United Kingdom in 1970. The growth of the past two decades has in all three countries outstripped the traditional capacity of the universities to be the chief instruments of fundamental research, with the result that specialised laboratories have sprung up throughout Northern Europe. The OECD team is right to draw attention to the way in which the existence of these new institutions has tended, paradoxically, to reduce the mobility of professional scientists and engineers engaged in fundamental research. And in spite of the efforts which have been made to increase the economic spin-off from applied research, the comparative survey concludes that none of the three countries dealt with has hit on an ideal solution. The underlying theme is that in spite of all the extra funds which have been devoted to research and development of all kinds,
Europe so far derives less benefit than does the United States from similar work.

Why should there be these differences and what should be done to remove them? There is a limit to the amount of improvement that might be looked for from further structural reorganization. The fact that all three European nations covered by the study have been equally disappointed by their investment in research and development in spite of having different methods of administration is by itself a proof that the ways in which government organizations are created are not strictly relevant. Structural differences between Europe and the United States of a more organic character may be more important. Where fundamental research is concerned, there are good reasons to suspect that clever people are much more easily moved between universities, research institutions and industry than in the United States. In applied research, European practice differs from American in that a smaller proportion of European expenditure by governments on applied research finds its way into the laboratories of commercial organizations before it is spent. One immediate result is that the link between applied research and commercial exploitation is much more tenuous in Europe than in the United States. And there are fewer strictly commercial enterprises in Europe which are as willing as successful American companies to regard research and development as a potentially beneficial investment. The OECD promises that the third part of the present study will be a comparison between the United States, Canada and Japan on the one hand and Europe on the other and these, it is to be hoped, are two of the crucial issues it will consider.

\section{Years Ago}

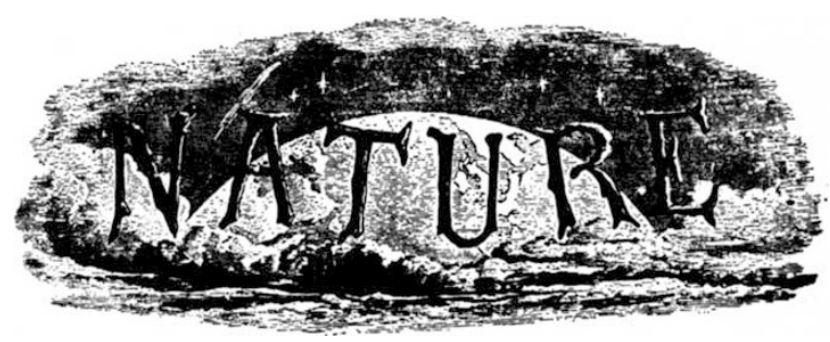

The Names Cambrian and Silurian in Geology

WiLl you allow me to express, as an humble worker among the rucks of North WVales, my sense of the high value of the contributions to your pages recently by Prof. Sterry Iunt on the "History of the names Cambrian and Silurian in Cieolozy?" I have long felt--and have not hesitated to express my feelingthat a great wrong was done to Prof. Sedswick when the North Wales groups of rocks from the Bala Beds to the Lingula Flags - the order of which he was the first to unravel in that difficult region-were unceremoniously engulphed in Siuria.

It has also appeared to me one of the greatest anomalies in English geological classification, that the magnificent and wall. defined groups of North Wales should be typitied by their attenuated and broken easterly outcrops in the Silurian district of South Shropshire. What Llandeilu seclion of Siluria is there that worthily represents the Arenig and lower Bala rocks inmediately east or west of the Ierwyn Mountains? What Caradoc section of Siluria is there at all worthy of the fine series of the Upper Bala rocks of Glyn Ceiriog? Of the unworthiness of the schists near the Stiper stones to represent the Lingula beds of North Wales, Prof. Hunt justly speaks in his papers.

I am glad that justice seem; at last likely to be done to the veteran, Prof. Sedgwick, than whom a more philosophical geololist I am persuasled does not exist. Let but a sufficient number of scientific men resolve to use his older and truer, because more natural classification, and the justice will soon be complete.

$$
\text { I). C. DATIES }
$$

